\title{
Effects of milk replacer feeding rates on growth performance of Holstein dairy calves to 4 months of age, evaluated via a meta-analytical approach
}

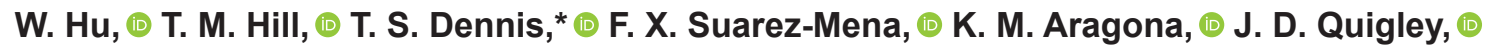 \\ and R. L. Schlotterbeck $($ ) \\ Nurture Research Center, Provimi, Cargill Animal Nutrition, Brookville, $\mathrm{OH} 45309$
}

\begin{abstract}
Our objective was to evaluate effects of feeding milk replacer (MR) at 2 feeding rates on digestion, intake, and growth of young dairy calves, via a meta-analytical approach using individual data. A database was developed from 10 published studies from the Nurture Research Center (Provimi; Brookville, $\mathrm{OH}$ ), in which 26 dietary treatments and 491 calves from 0 to $8 \mathrm{wk}$ of age in 13 nursery trials, and 22 dietary treatments and 485 calves from 8 to 16 wk of age in 13 grower trials occurred. Male Holstein calves $(\mathrm{n}=491$; initial body weight $42.8 \pm 4.9 \mathrm{~kg}$ ) were randomly assigned to 1 of 2 treatments: (1) moderate (MOD), 0.64 to $0.66 \mathrm{~kg}$ of dry matter (DM)/d for the first 35 to $39 \mathrm{~d}$, followed by half the allotment per $\mathrm{d}$ for 3 to $7 \mathrm{~d}$, fed at the a.m. feeding only; (2) high (HI), 0.92 to $1.07 \mathrm{~kg}$ of DM/d for the first 35 to $44 \mathrm{~d}$, followed by half the allotment per d for 5 to $7 \mathrm{~d}$, fed at the a.m. feeding only. Calves were weaned at 6 to 7 wk of age. Milk replacer ranged from 24.8 to $28.6 \%$ crude protein $(\mathrm{CP})$ and 17.6 to $20.2 \%$ fat; starter ranged from 17.3 to $22.2 \% \mathrm{CP}$ and 3.0 to $4.3 \%$ fat on a DM basis. On d 56 calves $(\mathrm{n}=485)$ moved into pens $(4$ calves/pen) by treatments and were fed starter (19.4 to $22.3 \% \mathrm{CP}$ and 3.4 to $4.6 \%$ fat, DM basis) blended with $5 \%$ hay until d 112. In all nursery trials (d 0 to 56), calves fed MOD had lower average daily gain (ADG; 0.634 vs. $0.545 \mathrm{~kg} / \mathrm{d})$, gain/DMI (0.488 vs. $0.466 \mathrm{~kg} /$ $\mathrm{kg}$ ), and hip width change (0.069 vs. $0.064 \mathrm{~cm} / \mathrm{d})$, but greater starter intake ( 0.473 vs. $0.696 \mathrm{~kg} / \mathrm{d}$ ) compared with calves fed HI. Apparent total-tract digestibility of DM (73.3 vs. $78.4 \%$ ), organic matter (OM; 74.1 vs. $79.0 \%$ ), CP (74.8 vs. $78.9 \%$ ), and neutral detergent fiber (NDF; 40.8 vs. $53.9 \%$ ) were greater for calves fed MOD vs. HI when estimated during wk 8 . In all grower trials (d 56 to 112), ADG (1.015 vs. $0.976 \mathrm{~kg} / \mathrm{d}$ ), gain/DMI ( 0.375 vs. $0.349 \mathrm{~kg} / \mathrm{kg}$ ), and hip width change $(0.089$ vs. $0.081 \mathrm{~cm} / \mathrm{d})$ were greater, but dry feed intake per
\end{abstract}

Received July 3, 2019.

Accepted November 11, 2019.

*Corresponding author: tdennis@provimi-na.com $\mathrm{kg}$ of $\mathrm{BW}^{0.75}$ did not differ $(87.8$ vs. $88.2 \mathrm{~g} / \mathrm{d}$ ) for calves previously fed MOD vs. HI. Apparent digestibility of DM (78.7 vs. $76.0 \%)$, OM (79.8 vs. $77.0 \%)$, CP (80.5 vs. $78.4 \%$ ), and NDF (54.8 vs. $45.8 \%$ ) were greater for calves fed MOD vs. HI when estimated between wk 11 to 13 . Over the entire 112-d period, calves fed MOD had lower ADG (0.805 vs. $0.784 \mathrm{~kg} / \mathrm{d}$ ) but tended to have greater hip width change $(8.415$ vs. $8.589 \mathrm{~cm})$ compared with calves fed HI. Under the conditions of this study, feeding higher MR rates caused calves to partially lose growth advantage during the weaning transition and further decreased BW gain and structural growth in the grower period (d 56 to 112), which could be due to reductions in nutrient digestibility as a result of feeding more MR.

Key words: calf, growth, digestibility, milk replacer

\section{INTRODUCTION}

Young calves are commonly fed restricted amounts of milk or milk replacer (MR; approx. $4 \mathrm{~L}$, or $10 \%$ of birth weight) daily. Pre-weaning ADG has been found to increase with increased milk or MR feeding (Diaz et al., 2001). Hence, interest has grown in feeding dairy calves more than the conventional amount. Dry (starter) feed consumption is important, as it initiates and promotes rumen development. Sufficient starter intake pre-weaning is necessary to maintain constant growth post-weaning (Bach, 2012). Feeding MR to calves at varying rates affects dry (starter) feed consumption. In recent years, extensive investigation has been carried out, to examine effects of milk or MR feeding rate (Kristensen et al., 2007; Bach et al., 2013; Schäff et al., 2016) and weaning age and procedures (Roth et al., 2009; Steele et al., 2017) on rumen development, health, and growth performance of calves, with an aim to optimize milk or MR feeding strategies for nursery calves. Nevertheless, after reviewing several studies evaluating feeding rates of milk or MR, Omidi-Mirzaei et al. (2015) reported inconsistent results among different studies. Such observed discrepancies might be due to differences in the amounts and quality of milk or 
MR fed, feeding methods, and management conditions among the studies. A question remains about how a high rate of MR feeding is necessary to maximize calf growth potential. Moreover, most data generated from each study were analyzed and reported individually. A compelling need exists, to compile all available data and conduct analyses to accurately quantify the overall growth performance of calves in response to MR feeding rates via a meta-analytical approach. Meta-analysis provides greater statistical power, compared with any single study, to detect treatment effects by substantially increasing the sample size studied (Lean et al., 2009).

Analyses reported herein are based on data collated from previous studies conducted at the Nurture Research Center (Provimi; Brookville, OH), in which male Holstein calves (initially $<1$ wk of age) were fed MR at different feeding rates. One objective of this study was to examine the effects of feeding MR at moderate or high rates on intake, apparent nutrient digestibility, and growth of dairy calves to 4 mo of age, using a metaanalytical approach. A secondary objective was to compare performance of calves fed differing MR rates with predicted energy- and protein-allowable growth rates from the NRC (2001) calf sub-model.

\section{MATERIALS AND METHODS}

Calves used in all studies were cared for according to acceptable practices as described in the Guide for the Care and Use of Agricultural Animals in Research and Teaching (FASS, 2010).

\section{Database}

Data used to examine effects of MR feeding rates on growth performance of dairy calves to 4 mo of age were collected from 10 published studies, which were conducted at the Nurture Research Center, located in southwest Ohio, from 2014 to 2016 (Hill et al. 2016a, 2018; Dennis et al., 2017, 2018a,b, 2019; Quigley et al., 2018, 2019a,b; Hu et al., 2019). At the time of publication of this study, these were all of the published studies from the center to contain the following information. Criteria for inclusion in analysis were a comparison of a moderate liquid feeding rate (defined as approximately $1.5 \%$ of initial BW on DM basis and similar across all trials) to a high liquid feeding rate (defined as approximately $2.5 \%$ of initial BW on DM basis), pre-weaning ADG and variation, pre-weaning starter intake and variation, total DM intake pre-weaning and variation, post-weaning ADG and variation, post-weaning DM intake and variation, 8 to $10 \mathrm{wk}$ post-weaning ADG and feed-intake data, and digestibility estimates pre- and post-weaning. The majority of studies in the literature comparing liquid feeding rates compare only a low rate $(454 \mathrm{~g} / \mathrm{d}$ on an as-fed basis of solids) with a high rate $(>1,000 \mathrm{~g} / \mathrm{d}$ on an as-fed basis of solids), do not report data beyond 4 wk after weaning, or do not report digestibility estimates. Additional criteria were the use of calves from 1 farm, ages of less than $4 \mathrm{~d}$ when trials began, and feeds within trial manufactured sequentially from the same ingredients. Use of raw data from individual calves allows for more statistical power than does the use of treatment means and is the gold standard in meta-analyses (Lean et al., 2009). The database consisted of 4 data sets: (1) nursery ( 0 to 8 wk of age), 13 trials including 26 dietary treatments and 491 calves; (2) grower ( 8 to $16 \mathrm{wk}$ of age), 13 trials including 22 dietary treatments, 124 pens, and 485 calves; (3) entire growth period ( 0 to $16 \mathrm{wk}$ ), a combination of nursery and grower data sets including 22 dietary treatments, 124 pens, and 485 calves; and (4) digestibility, in which nutrient digestibility was measured in post-weaned calves at $8 \mathrm{wk}$ of age (Dennis et al., 2018b; Quigley et al., 2018; Hu et al., 2019), wk 11 to 13 (Hill et al., 2016a; Dennis et al., 2018a; Quigley et al., 2018), or wk 16 (Hill et al., 2016a; Dennis et al., 2018a; Quigley et al., 2018).

Across all trials in 10 studies (Table 1), results were reported of the effects of varying MR feeding rates in nursery calves; moreover, the carryover effects of preweaning MR feeding rates was evaluated in the same calves in the following grower period (2 to 4 mo of age). Milk replacer feeding rates were categorized according to the average amount of MR fed daily pre-weaning (Table 2) and defined as moderate (MOD), 0.64 to $0.66 \mathrm{~kg}$ of $\mathrm{DM} / \mathrm{d}(681 \mathrm{~g} / \mathrm{d}$ on an as-fed basis, calves fed uniformly the same amount daily); or high (HI), 0.92 to $1.07 \mathrm{~kg}$ of DM/d. Feeding rates outside these ranges were not used. For calves fed MOD, MR was halved into a.m. and p.m. feedings for 35 to $39 \mathrm{~d}$, followed by a.m. feeding of half of the previous MR amount for 3 to $7 \mathrm{~d}$ (Table 2). For calves fed HI, MR feeding regimens were more variable among the trials in 10 studies, of which there were constant (Hu et al., 2019), step-up (Hill et al., 2016a; Dennis et al., 2017, 2018a, and 2019; Quigley et al., 2018 and 2019a), or step-up and step-down (Dennis et al., 2018b) MR feeding programs pre-weaning. In general, calves fed HI consumed equal amounts of MR twice daily (a.m. and p.m. feeding) for a period of 35 to $44 \mathrm{~d}$, followed by a.m. feeding of half of the previous MR amount for 5 to $7 \mathrm{~d}$ (Table 2). An exception occurred in study of Dennis et al. (2018b), in which, after step-down MR feeding in wk 6, HI-fed calves consumed half of the MR allotment in wk 6 once daily (a.m. feeding) for $4 \mathrm{~d}$, thereafter followed by half the allotment fed during the previous $4 \mathrm{~d}$ for an extension of $3 \mathrm{~d}$ (Table 2). Milk replacer was diluted with 


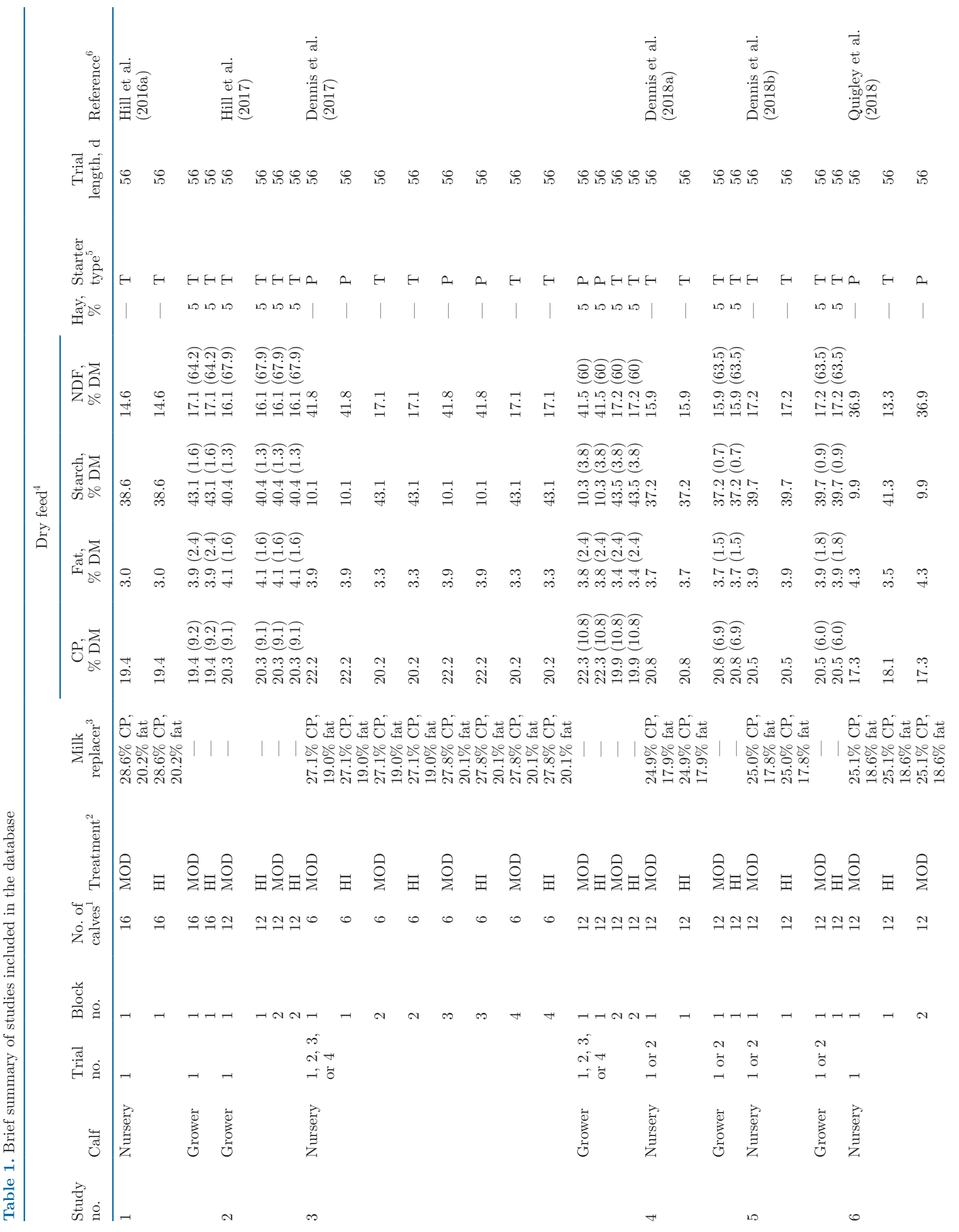


Hu et al.: MILK REPLACER RATE AND CALF PERFORMANCE

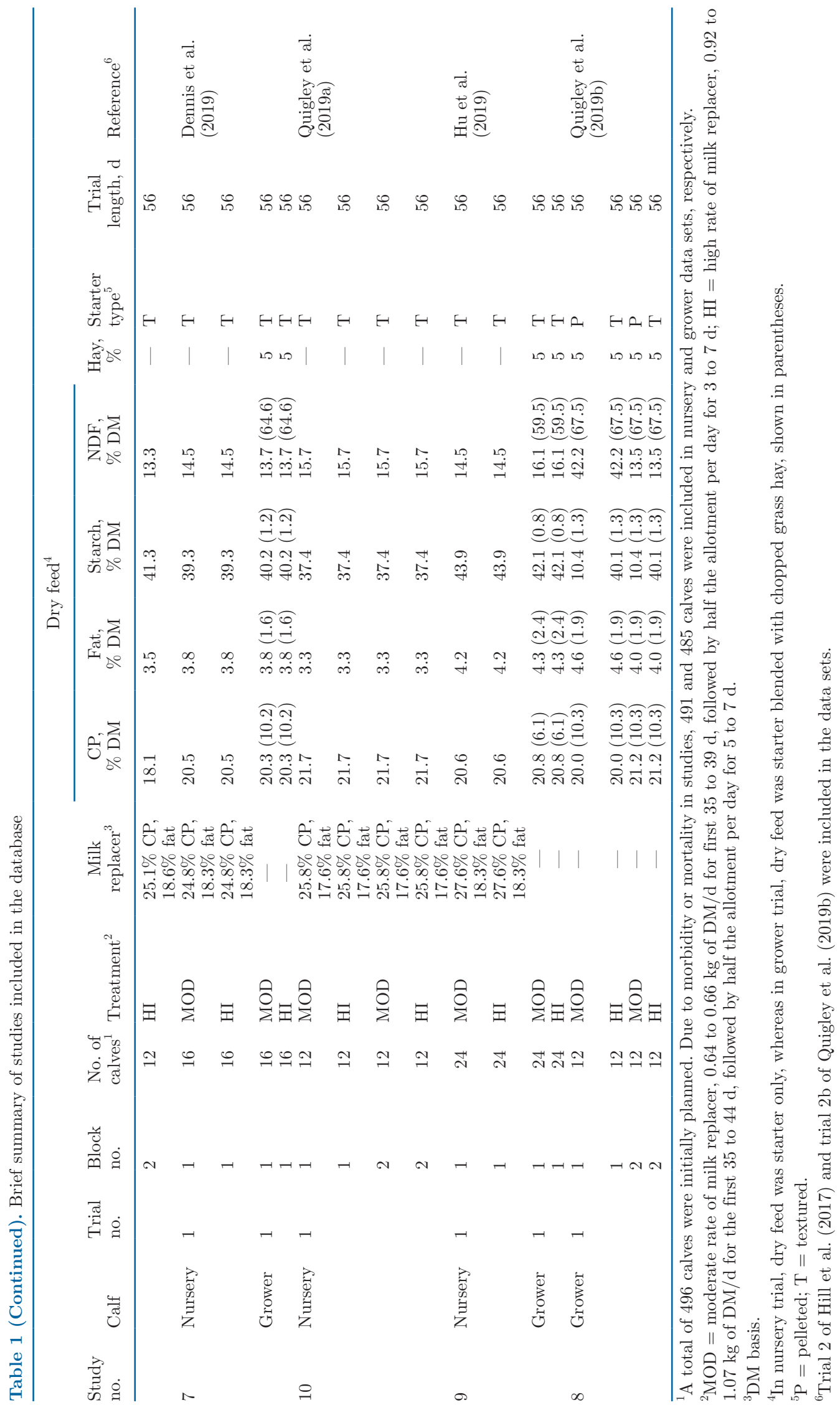


Hu et al.: MILK REPLACER RATE AND CALF PERFORMANCE

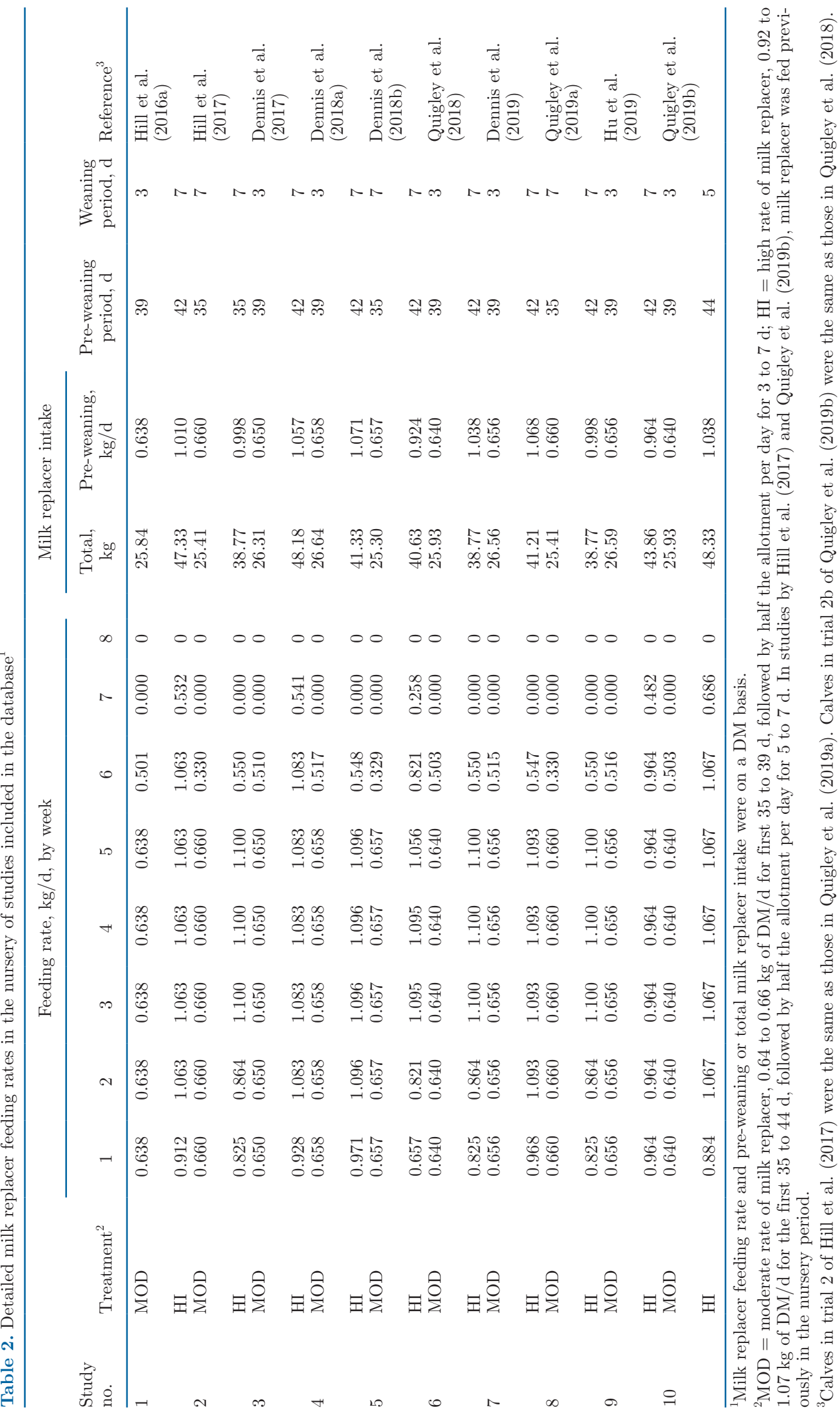


water to 12 to $15 \%$ DM before feeding, depending on the trial.

All calves were Holstein males, initially less than 4 $\mathrm{d}$ of age, and were housed in $1.2 \times 2.4$-m individual pens in a curtain-sided, naturally ventilated barn with no added heat. The pens were separated by wire-mesh panels, with a coarse rock, tile-drained floor bedded with straw.

Rejected MR was weighed back after each feeding. Starter and water were offered for ad libitum intake throughout the nursery period. Every other bag of MR and calf starter was sampled and composited for nutrient analysis. Feces were scored daily using a scale from 1 to 5 , with 1 being normal and 5 being watery (modified from Kertz and Chester-Jones, 2004). Fecal score $\geq 3$ was considered abnormal, and a day with an abnormal fecal score was counted as one abnormal fecal day. Antibiotic medical treatment was based on a binomial scoring system of lethargy, coughing, nasal discharge, or rectal temperature $>39.4^{\circ} \mathrm{C}$. Calves with fecal scores $>2$ received oral electrolytes, but these were not counted as medical treatments. Medical treatments were recorded daily, and a day with medical treatment was counted as one medical day. Calves were weighed weekly, and hip widths were measured on $\mathrm{d} 0$ and every 2 wk thereafter.

On d 56, calves from the nursery period were grouped by pre-weaning treatment and moved to pens (mostly 4 calves/pen) until $112 \mathrm{~d}$ of age. The pens had $6.5 \mathrm{~m}^{2}$ of outside pen space and 0.9 to $1.35 \mathrm{~m}^{2}$ of inside pen space per calf, bedded with wheat straw. In the grower period (d 56 to 112), calves were fed the same starter as in the nursery period, blended with chopped grass hay (Table 1) for ad libitum intake, with unrestricted access to water. Grower feed refusals were weighed daily to determine DM intake. Every other bag of starter and every bale of hay was sampled and composited for nutrient analysis. Calf BW and hip width were determined on d 56, 84, and 112 .

Five calves per treatment were randomly selected for use in a period of $5 \mathrm{~d}$ to estimate nutrient digestibility post-weaning in the nursery period. Fecal grab samples were collected via rectal palpation from each calf and composited by calf. In the grower period, fecal samples were collected daily in a period of $5 \mathrm{~d}$ from the pen floors, with care taken not to sample bedding or other floor materials, and composited by pen. The nursery and group pens were bedded with long wheat straw, and straw consumption by calves was possible (Hill et al., 2010, 2016b). However, new bedding was not added just before or during fecal collection periods for estimation of digestibility, to minimize the chance of straw intake. A recent study (Hill et al., 2019) suggested that long wheat straw as bedding would not change esti- mates of digestion in young Holstein calves. Therefore, the effects on digestion by potential consumption of bedding could be trivial and were not considered. Quigley et al. (2018) measured digestibility in wk 11 and 13; the mean of both measurements was used for analysis.

Detailed methods of nutrient analysis and total-tract digestibility estimate, management practices including vaccines, castration, and dehorning, and any specific treatment application in each individual trial are provided in the original studies (Table 1 ). Mean, standard deviation, and minimal and maximal values for all major selected variables are shown in Table 3.

\section{Statistical Analysis}

In the nursery period, data of daily intakes were reduced to weekly means for each calf. Energy- and apparent digestible protein (DP)-allowable ADG were predicted using the young calf model in NRC (2001), with inputs of calf BW, ambient temperature, and nutrients of MR and starter. In the grower period, data of daily intakes were reduced to means in 28 -d periods for each pen of calves. The entire growth period data set (0 to $16 \mathrm{wk}$ ) was a combination of calves in the nursery and grower periods, in which nursery calves were reorganized by treatment and pen based on the experimental structure in the grower. Therefore, the pen for nursery calves was set up the same as in the grower stage; accordingly, data of MR, intake, and other factors for each individual calf in the nursery period were calculated as means for each pen. In several studies (Dennis et al., 2017; Hill et al., 2018; Quigley et al., 2018, 2019a,b), most of the trials were conducted in an experimental design with factorial arrangement of treatments (Table 1). Based on the treatment structure in those trials, independent comparison of dietary treatments was constructed. Each comparison was considered specifically as a "block" being included in the statistical model for further analysis, which would be the most appropriate way to detect true responses resulting only from varying MR feeding rates in the diets. Effects of MR feeding rates among trials in each of 4 sub-data sets were examined using the PROC MIXED model in SAS (SAS Institute Inc., 2012). Calf in the nursery or digestibility (wk 8) data sets, or pen in grower or entire growth period (d 0 to 112), or digestibility (wk 11 to 13 or 16) data sets were the experimental units. Trial and block(trial) were considered to be random variables. In the mixed models with repeated measurements in periods of day, week, or 14- or 28-d, when applicable, calf or pen were treated as random variables. For construction of covariance structure, the data were grouped by SUBJECT $=$ block $\times$ calf(trial) or block $\times$ pen(trial) whenever experimental units were calf or pen, respectively. 
Table 3. Mean and range of selected variables in the database

\begin{tabular}{|c|c|c|c|c|c|}
\hline Variable & No. ${ }^{1}$ & Mean & $\mathrm{SD}$ & Minimum & Maximum \\
\hline \multicolumn{6}{|l|}{ Nursery } \\
\hline Initial BW, kg & 491 & 42.8 & 4.9 & 29.4 & 57.7 \\
\hline Initial hip width, $\mathrm{cm}$ & 491 & 17.48 & 0.96 & 14.50 & 19.75 \\
\hline $\mathrm{ADG}, \mathrm{kg} / \mathrm{d}$ & 491 & 0.588 & 0.139 & 0.143 & 0.957 \\
\hline Starter intake, $\mathrm{kg} / \mathrm{d}$ & 491 & 0.588 & 0.237 & 0.052 & 1.299 \\
\hline DMI, $\mathrm{kg} / \mathrm{d}$ & 491 & 1.245 & 0.214 & 0.642 & 1.801 \\
\hline $\mathrm{DMI} / \mathrm{BW}^{0.75}, \mathrm{~kg} / \mathrm{kg}$ & 491 & 0.059 & 0.008 & 0.032 & 0.081 \\
\hline ADG:DMI, kg/kg & 491 & 0.477 & 0.086 & 0.099 & 0.870 \\
\hline Hip width change, $\mathrm{cm} / \mathrm{d}$ & 491 & 0.067 & 0.017 & 0.018 & 0.116 \\
\hline \multicolumn{6}{|l|}{ Grower } \\
\hline Initial BW, kg & 124 & 76.1 & 7.0 & 57.7 & 91.3 \\
\hline Initial hip width, cm & 124 & 21.28 & 0.81 & 19.19 & 23.67 \\
\hline $\mathrm{ADG}, \mathrm{kg} / \mathrm{d}$ & 124 & 0.996 & 0.104 & 0.744 & 1.208 \\
\hline DMI, kg/d & 124 & 2.827 & 0.443 & 1.606 & 3.658 \\
\hline $\mathrm{DMI} / \mathrm{BW}^{0.75}, \mathrm{~kg} / \mathrm{kg}$ & 124 & 0.087 & 0.011 & 0.054 & 0.114 \\
\hline ADG:DMI, $\mathrm{kg} / \mathrm{kg}$ & 124 & 0.362 & 0.055 & 0.245 & 0.528 \\
\hline Hip width change, $\mathrm{cm} / \mathrm{d}$ & 124 & 0.085 & 0.012 & 0.057 & 0.113 \\
\hline \multirow{2}{*}{\multicolumn{6}{|c|}{$\begin{array}{l}\text { Digestibility } \\
\text { wk } 8\end{array}$}} \\
\hline & & & & & \\
\hline DM, \% & 40 & 75.8 & 4.5 & 64.8 & 82.9 \\
\hline $\mathrm{CP}, \%$ & 40 & 76.9 & 4.5 & 67.4 & 84.0 \\
\hline NDF, $\%$ & 40 & 47.4 & 16.1 & 12.0 & 75.8 \\
\hline Fat, $\%$ & 40 & 85.5 & 6.2 & 68.3 & 94.7 \\
\hline Starch, \% & 40 & 95.6 & 3.2 & 87.4 & 99.3 \\
\hline \multicolumn{6}{|l|}{ wk $11-13$} \\
\hline DM, \% & 26 & 76.9 & 5.3 & 67.7 & 86.5 \\
\hline $\mathrm{CP}, \%$ & 26 & 78.9 & 5.3 & 67.4 & 88.5 \\
\hline NDF, $\%$ & 26 & 48.8 & 16.6 & 22.9 & 70.5 \\
\hline Fat, $\%$ & 26 & 82.7 & 3.5 & 75.2 & 87.7 \\
\hline Starch, \% & 26 & 95.6 & 2.2 & 88.9 & 100.0 \\
\hline \multicolumn{6}{|l|}{ wk 16} \\
\hline DM, \% & 26 & 82.6 & 3.4 & 74.0 & 88.2 \\
\hline $\mathrm{CP}, \%$ & 26 & 85.1 & 2.8 & 77.5 & 89.9 \\
\hline $\mathrm{NDF}, \%$ & 26 & 66.0 & 4.6 & 58.6 & 76.6 \\
\hline Fat, \% & 26 & 87.3 & 4.4 & 77.6 & 92.3 \\
\hline Starch, \% & 26 & 95.8 & 2.9 & 88.8 & 100.0 \\
\hline
\end{tabular}

${ }^{1}$ Number of calves for variables in the nursery and digestibility (wk 8); number of pens for variables in the grower and digestibility (wk 11 to 13 and 16).

The first-order autoregressive structure was selected as the appropriate covariance structure based on Akaike's information criterion. Significance was declared at $P$ $\leq 0.05$, whereas $0.05<P \leq 0.10$ was considered to indicate a trend toward a significant effect.

\section{RESULTS}

\section{Characteristics of the Database}

Table 1 provides a summary of the studies in the database. There were 491 Holstein male dairy calves in nursery trials and 124 pens (485 calves) in grower trials. Milk replacer differed among nursery trials, with contents of protein and fat in the MR ranging from 24.8 to $28.6 \%$, and 17.6 to $20.2 \%$ on DM basis, respectively. Concentrations of CP, fat, and NDF of starters in the nursery trials ranged from 17.3 to $22.2 \%, 3.0$ to $4.3 \%$, and 13.3 to $41.8 \%$ on DM basis, respectively. Although starters in the grower trials were the same as those in the nursery trials, nutrient values differed slightly, as shown in Table 1, as the nutrient analyses were conducted with samples from different batches of starter.

Detailed MR feeding regimens in the nursery are shown in Table 2. Total MR intakes and pre-weaning feeding rates ranged from 25.30 to $26.64 \mathrm{~kg}, 0.638$ to $0.660 \mathrm{~kg} \mathrm{DM} / \mathrm{d}$, respectively, for calves fed MOD, and from 38.77 to $48.33 \mathrm{~kg}, 0.924$ to $1.071 \mathrm{~kg} \mathrm{DM} / \mathrm{d}$, respectively, for calves fed HI. Calves fed MOD started weaning 3 to $7 \mathrm{~d}$ earlier than calves fed HI (Table 2), with an exception that calves fed MR at both rates started weaning at the same time in the study of Hill et al. (2018).

\section{Nutrient Intake}

During the pre-weaning period ( $\mathrm{d} 0$ to 35; Table 4), MOD-fed calves had lesser intakes per kilogram of $\mathrm{BW}^{0.75}(P<0.001)$ of total DM, ME, fat, CP, and DP, but greater intakes per kilogram of $\mathrm{BW}^{0.75}(P<0.001)$ 
Hu et al.: MILK REPLACER RATE AND CALF PERFORMANCE

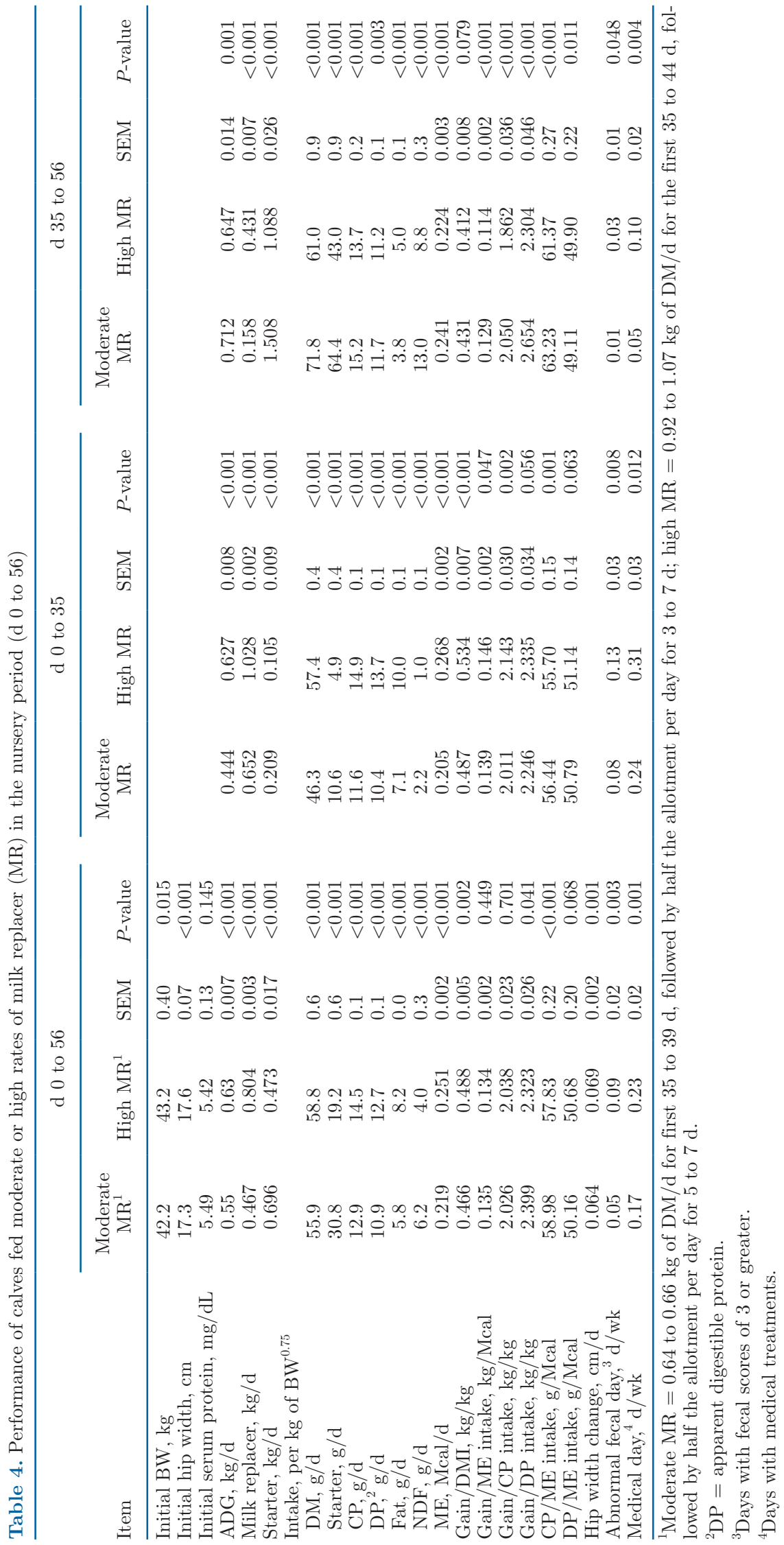


Table 5. Predicted energy- and DP-allowable gain for calves fed moderate or high rates of milk replacer in the nursery period (d $0-56)$

\begin{tabular}{|c|c|c|c|c|}
\hline \multirow[b]{2}{*}{ Item $^{1}$} & \multicolumn{2}{|c|}{ Milk replacer ${ }^{2}$} & \multirow[b]{2}{*}{ SEM } & \multirow[b]{2}{*}{$P$-value } \\
\hline & Moderate & High & & \\
\hline \multicolumn{5}{|l|}{ d 0 to 35} \\
\hline Energy-allowable gain, $\mathrm{kg} / \mathrm{d}$ & 0.540 & 0.887 & 0.014 & $<0.001$ \\
\hline $\mathrm{DP}^{3}$-allowable gain, $\mathrm{kg} / \mathrm{d}$ & 0.659 & 0.986 & 0.020 & $<0.001$ \\
\hline Energy-allowable gain - actual ADG, $\mathrm{kg} / \mathrm{d}$ & 0.133 & 0.309 & 0.009 & $<0.001$ \\
\hline DP-allowable gain-actual ADG, $\mathrm{kg} / \mathrm{d}$ & 0.250 & 0.412 & 0.008 & $<0.001$ \\
\hline \multicolumn{5}{|l|}{ d 35 to 56} \\
\hline Energy-allowable gain, $\mathrm{kg} / \mathrm{d}$ & 0.671 & 0.656 & 0.027 & 0.393 \\
\hline DP-allowable gain, $\mathrm{kg} / \mathrm{d}$ & 0.821 & 0.873 & 0.027 & 0.002 \\
\hline Energy-allowable gain - actual ADG, $\mathrm{kg} / \mathrm{d}$ & -0.014 & 0.044 & 0.010 & $<0.001$ \\
\hline DP-allowable gain - actual ADG, $\mathrm{kg} / \mathrm{d}$ & 0.125 & 0.254 & 0.010 & $<0.001$ \\
\hline \multicolumn{5}{|l|}{ d 0 to 56} \\
\hline Energy-allowable gain, $\mathrm{kg} / \mathrm{d}$ & 0.591 & 0.803 & 0.019 & $<0.001$ \\
\hline DP-allowable gain, $\mathrm{kg} / \mathrm{d}$ & 0.722 & 0.947 & 0.017 & $<0.001$ \\
\hline Energy-allowable gain - actual ADG, kg/d & 0.078 & 0.210 & 0.006 & $<0.001$ \\
\hline DP-allowable gain-actual ADG, kg/d & 0.203 & 0.353 & 0.006 & $<0.001$ \\
\hline
\end{tabular}

${ }^{1}$ Energy- and DP-allowable gain were predicted based on NRC (2001).

${ }^{2}$ Moderate milk replacer $=0.64$ to $0.66 \mathrm{~kg}$ of DM/d for first 35 to $39 \mathrm{~d}$, followed by half the allotment per day for 3 to $7 \mathrm{~d}$; high milk replacer $=0.92$ to $1.07 \mathrm{~kg}$ of DM/d for the first 35 to $44 \mathrm{~d}$, followed by half the allotment per day for 5 to $7 \mathrm{~d}$.

${ }^{3} \mathrm{DP}=$ apparent digestible protein.

of starter and NDF compared with HI-fed calves. During the weaning transition period (d 35 to 56), MODfed calves had greater intakes per kilogram of $\mathrm{BW}^{0.75}(P$ $<0.005)$ of total DM, starter, ME, CP, DP, and NDF compared with HI-fed calves. Over the entire nursery period (d 0 to 56), MOD-fed calves had lesser intakes per kilogram of $\mathrm{BW}^{0.75}(P<0.001)$ of total DM, CP, $\mathrm{DP}$, fat, and $\mathrm{ME}$, but greater intakes $(P<0.001)$ of

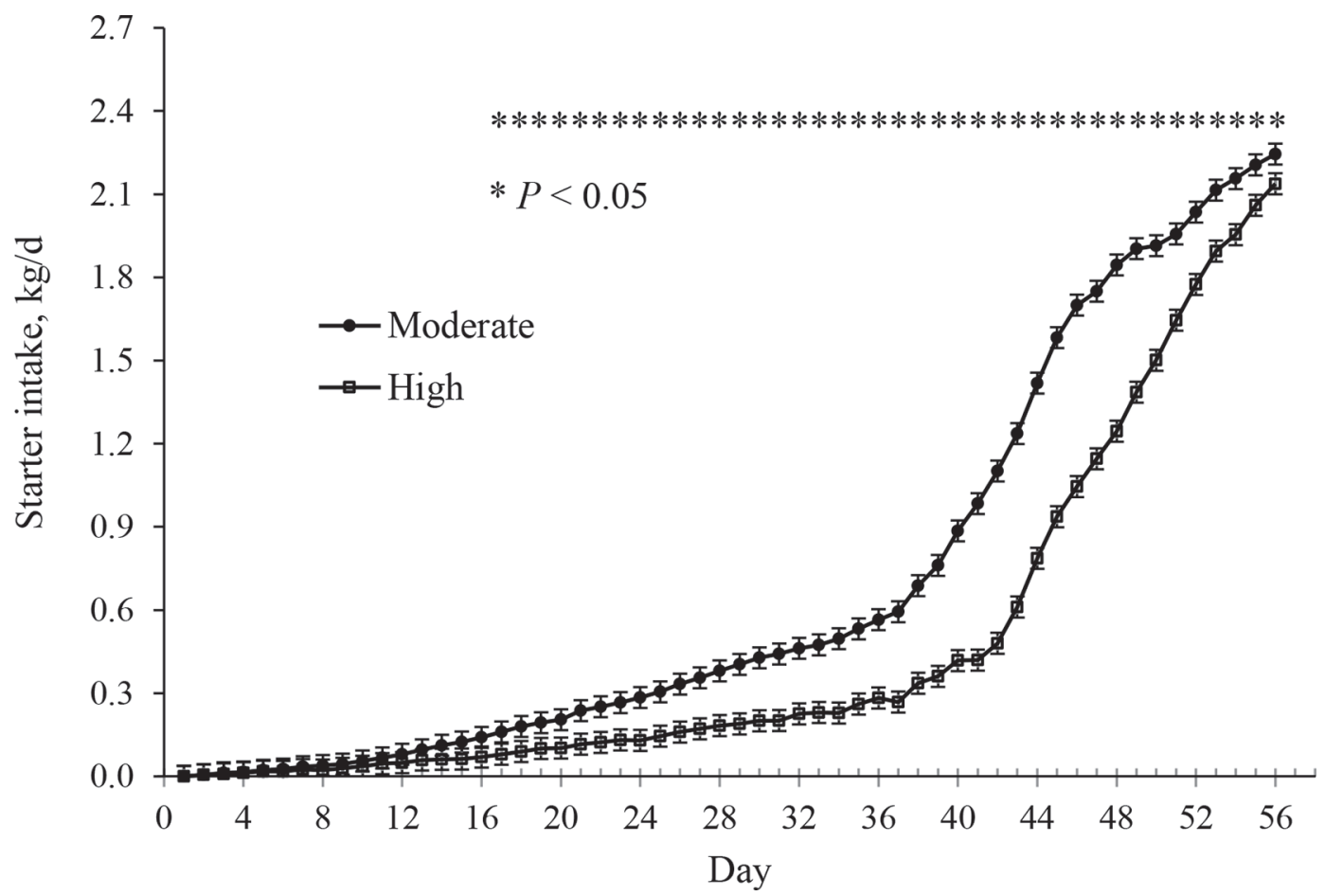

Figure 1. Starter intake pattern for Holstein calves fed moderate or high rates of milk replacer in the nursery period. Moderate $=0.64$ to 0.66 $\mathrm{kg}$ of $\mathrm{DM} / \mathrm{d}$ for the first 35 to $39 \mathrm{~d}$, followed by half the allotment per day for 3 to $7 \mathrm{~d}$; high $=0.92$ to $1.07 \mathrm{~kg}$ of $\mathrm{DM} / \mathrm{d}$ for the first 35 to $44 \mathrm{~d}$, followed by half the allotment per day for 5 to $7 \mathrm{~d}$. Asterisks indicate that starter intake at the same week differed in the calves fed moderate vs. high rates of milk replacer $(P<0.05)$. Bars indicate SEM (moderate $=0.038 \mathrm{~kg} / \mathrm{d}$; high $=0.038 \mathrm{~kg} / \mathrm{d}$ ). 


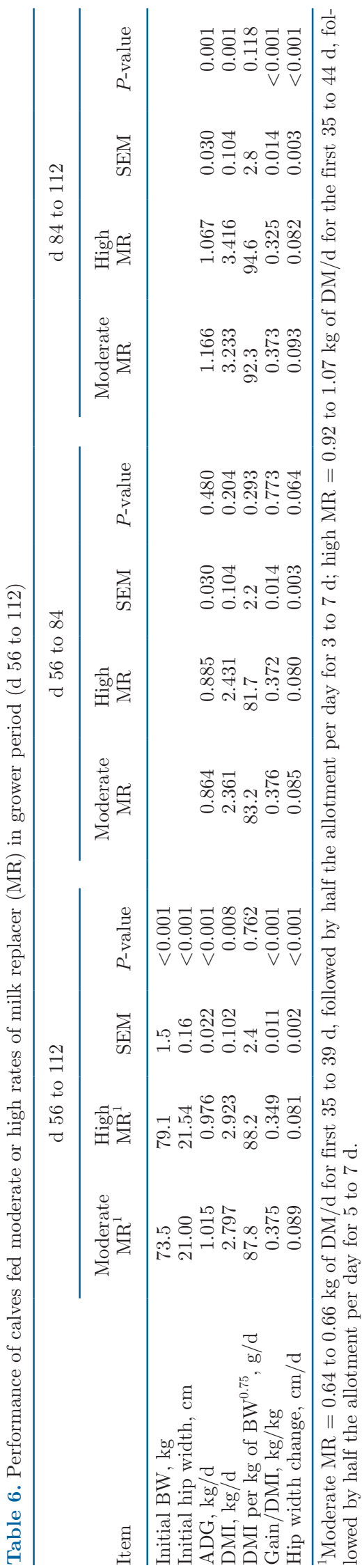

starter and NDF than HI-fed calves. The evolution of starter intake as feeding day progressed was different between the $2 \mathrm{MR}$ feeding rates (Figure 1). Regardless of MR feeding rates offered to calves, starter intake was very low during the first $2 \mathrm{wk}$ of age and remained similar until d 16. From d 17 to the end of the nursery period, MOD-fed calves had greater starter intake $(P<$ 0.05) on each day compared with HI-fed calves.

During the grower period (d 56 to 112; Table 5), DMI did not differ from d 56 to 84 but was lesser from d 84 to 112 for calves fed MOD compared with those fed HI. Over the entire grower period (d 56 to 112), MOD-fed calves consumed $4.3 \%$ less feed per d compared with HI-fed calves. Nevertheless, DMI per kilogram of BW ${ }^{0.75}$ in calves fed MOD compared with HI was similar in the first half (d 56 to 84), the second half (d 84 to 112), and over the entire grower period (d 56 to 112). Throughout the nursery and grower periods (d 0 to 112; Table 6), calves fed MOD versus HI consumed $5.6 \%$ less total DM $(P<0.001)$ and had $4.1 \%$ less DMI per kilogram of $\mathrm{BW}^{0.75}(P<0.001)$ but tended to have $2.6 \%$ greater total dry feed intake $(P=0.100)$.

\section{Growth Performance}

Weekly ADG for both MR feeding rates in the nursery period, along with calculated energy-, and DPallowable ADG based on NRC (2001) are shown in Figure 2. Calves fed MOD had less ADG during the first $35 \mathrm{~d}$ but greater ADG during the weaning transition period (d 35 to 56 ) than did HI-fed calves $(P<0.001)$. Overall ADG and hip width change across the entire nursery period (d 0 to 56 ) was $14 \%$ and $7 \%$ less in MOD- compared with HI-fed calves $(P<0.001)$. Over the entire nursery period (d 0 to 56), efficiencies of ME and $\mathrm{CP}$ utilization did not differ, but feed efficiency $(P$ $=0.002)$ and efficiency of DP utilization $(P=0.041)$ were higher in MOD- than HI-fed calves (Table 4). Calves fed MOD had less energy- and DP-allowable gain during the first $35 \mathrm{~d}$ than did calves fed $\mathrm{HI}(P<$ 0.001; Table 5). However, during the weaning transition, MOD-fed calves had similar energy-allowable gain compared with HI-fed calves. Over the entire nursery period, MOD-fed calves showed less energy- and DPallowable gain than did HI-fed calves $(P<0.001)$.

During the first half of the grower period (d 56 to 84; Table 6), ADG and BW gain per kilogram of DMI did not differ, but hip width change tended to be $6.3 \%$ greater in calves fed MOD than in those fed HI $(P=$ $0.064)$. During the second half of the grower period (d 84 to 112 ), ADG, BW gain per kilogram of DMI, and hip width change were $9.3 \%, 14.8 \%$, and $13.4 \%$ greater for calves fed MOD versus HI $(P<0.001)$. Over the entire grower period (d 56 to 112), MOD-fed calves had 
4.0\% greater ADG, $7.4 \%$ greater BW gain per kilogram of DMI, and $9.9 \%$ greater hip width change compared with HI-fed calves $(P<0.001)$.

Throughout the entire $112 \mathrm{~d}$ (Table 7), calves previously fed MOD versus HI in the nursery had $2.6 \%$ and
$5.6 \%$ less ADG and DMI, respectively $(P<0.005)$. However, calves previously fed MOD had $3.3 \%$ greater BW gain per kilogram of DMI $(P=0.013)$ and tended to have $2.1 \%$ greater hip width change $(P=0.081)$ compared with calves previously fed HI.

(a) Moderate

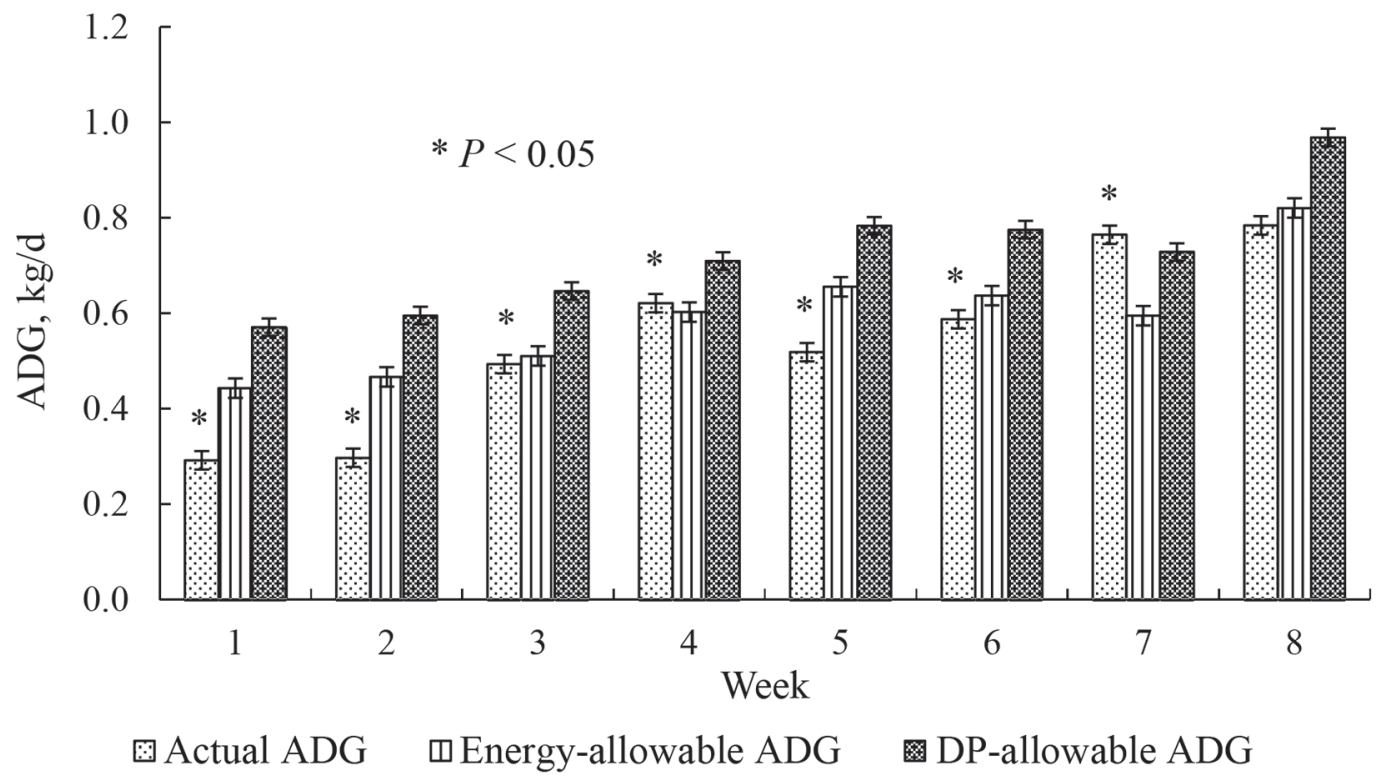

(b) High

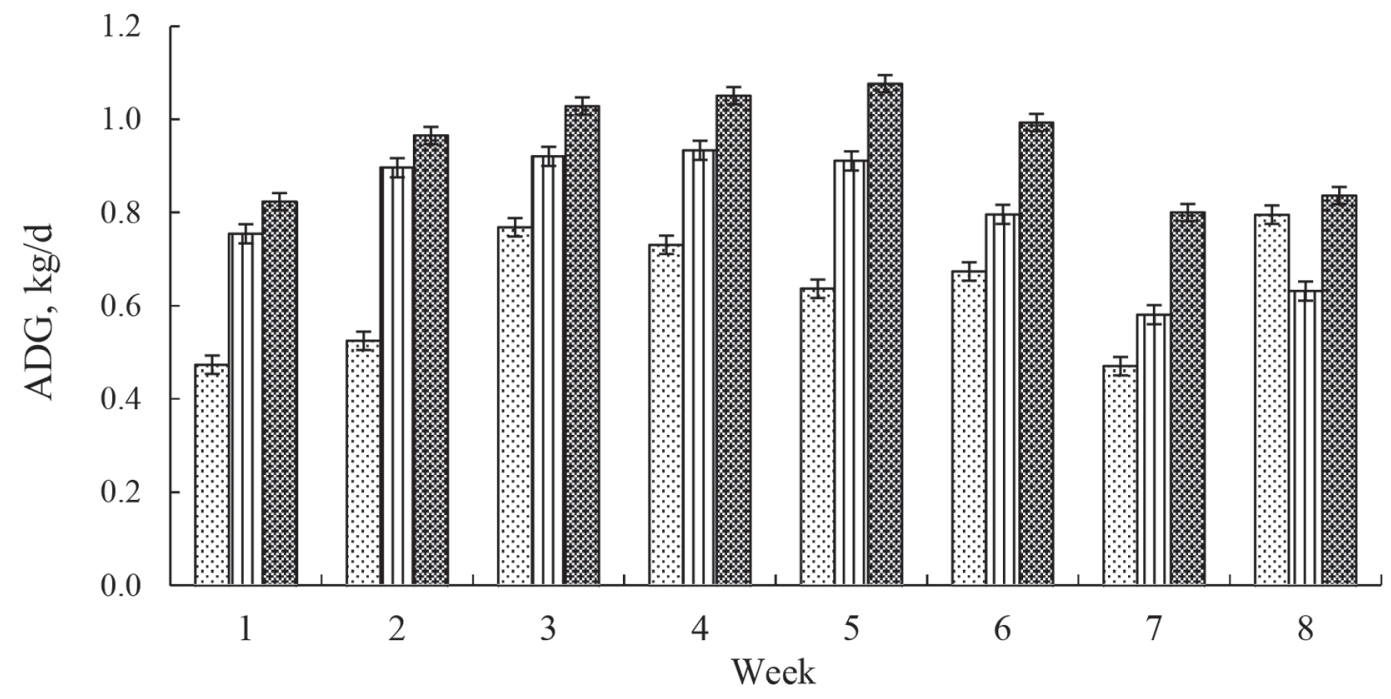

Actual ADG $\square$ Energy-allowable ADG 圈DP-allowable ADG

Figure 2. Actual ADG, energy-allowable ADG, and apparent digestible protein (DP)-allowable ADG in calves fed moderate or high rates of milk replacer in the nursery period. Moderate $=0.64$ to $0.66 \mathrm{~kg}$ of DM/d for first 35 to $39 \mathrm{~d}$, followed by half the allotment per day for 3 to 7 $\mathrm{d}$; high $=0.92$ to $1.07 \mathrm{~kg}$ of DM/d for the first 35 to $44 \mathrm{~d}$, followed by half the allotment per day for 5 to 7 d. Energy- and DP-allowable ADG were calculated based on NRC (2001). Asterisks indicate that actual ADG at the same week differed in the calves fed moderate vs. high rates of milk replacer $(P<0.05)$. Bars indicate SEM. Moderate: actual ADG $=0.019 \mathrm{~kg} / \mathrm{d}$; energy-allowable ADG $=0.020 \mathrm{~kg} / \mathrm{d} ;$ DP-allowable ADG $=0.018 \mathrm{~kg} / \mathrm{d}$. High: actual ADG $=0.020 \mathrm{~kg} / \mathrm{d}$; energy-allowable ADG $=0.021 \mathrm{~kg} / \mathrm{d} ;$ DP-allowable ADG $=0.019 \mathrm{~kg} / \mathrm{d}$. 
Table 7. Performance of calves fed moderate or high rates of milk replacer (MR; d 0 to 112) ${ }^{1}$

\begin{tabular}{|c|c|c|c|c|}
\hline \multirow[b]{2}{*}{ Item } & \multicolumn{2}{|c|}{ MR } & \multirow[b]{2}{*}{ SEM } & \multirow[b]{2}{*}{$P$-value } \\
\hline & Moderate & High & & \\
\hline $\mathrm{ADG}, \mathrm{kg} / \mathrm{d}$ & 0.784 & 0.805 & 0.019 & 0.004 \\
\hline DMI, $\mathrm{kg} / \mathrm{d}$ & 1.987 & 2.105 & 0.062 & $<0.001$ \\
\hline DMI per $\mathrm{kg}$ of $\mathrm{BW}^{0.75}, \mathrm{~g} / \mathrm{d}$ & 70.0 & 73.0 & 1.6 & $<0.001$ \\
\hline Total MR intake, $\mathrm{kg}$ & 26.14 & 44.43 & 0.61 & $<0.001$ \\
\hline Total dry feed intake, $\mathrm{kg}$ & 196.51 & 191.43 & 7.12 & 0.100 \\
\hline Gain/DMI, kg/kg & 0.403 & 0.390 & 0.007 & 0.013 \\
\hline Hip width change, $\mathrm{cm}$ & 8.589 & 8.415 & 0.195 & 0.081 \\
\hline
\end{tabular}

${ }^{1}$ Moderate $\mathrm{MR}=0.64$ to $0.66 \mathrm{~kg}$ of $\mathrm{DM} / \mathrm{d}$ for first 35 to $39 \mathrm{~d}$, followed by half the allotment per day for 3 to $7 \mathrm{~d}$; high $\mathrm{MR}=0.92$ to $1.07 \mathrm{~kg}$ of $\mathrm{DM} / \mathrm{d}$ for the first 35 to $44 \mathrm{~d}$, followed by half the allotment per day for 5 to $7 \mathrm{~d}$.

\section{Apparent Nutrient Digestibility}

Apparent nutrient digestibility was evaluated after weaning in the nursery period (wk 8; Table 8). The digestibility of DM, OM, CP, and NDF were greater $(P$ $\leq 0.001)$, but starch $(P=0.807)$ and fat $(P=0.131)$ were similar for MOD- and HI-fed calves. Apparent nutrient digestibility was also evaluated in the grower period (wk 11 to 13 and wk 16; Table 8). In wk 11 to 13 , greater digestibility of $\mathrm{DM}, \mathrm{OM}, \mathrm{CP}, \mathrm{NDF}$, and fat $(P \leq 0.02)$, and similar digestibility of starch $(P$ $=0.441)$ were observed in calves previously fed MOD versus HI. Nutrient digestibility did not differ $(P>$ 0.100; Table 8) in wk 16 for calves previously fed MOD compared with HI.

\section{DISCUSSION}

The objective of this study was to investigate the effects of feeding MR at high or moderate rates in the nursery on growth performance in Holstein calves to 4 mo of age. A moderate feeding rate was chosen as a control group, because typical MR feeding rates in the US dairy industry have increased from 0.45 to 0.57 $\mathrm{kg} / \mathrm{d}$ or as high as $0.68 \mathrm{~kg} / \mathrm{d}$ (Kertz and Loften, 2013). During the last decade, feeding calf MR at a rate higher than $0.68 \mathrm{~kg} / \mathrm{d}$ has gained significant interest, and accelerated calf feeding programs have been increasingly implemented on dairy farms globally. Therefore, we chose a group of increased MR feeding rates, HI, for comparison in the current study. We opted to base HI on a selected range because it is important to understand the growth potential and subsequent carryover influence at a later stage of life when Holstein calves are fed MR at such high rates. Divergent MR feeding regimens occurred in calves fed HI. In fact, it was not feasible to collate data from varied studies to create an HI group having uniform MR feeding regimens, as it was in the MOD group (Table 2). Moreover, it should be noted that $2 \mathrm{MR}$ feeding rates in the current study were confounded with weaning age and period (Table 2 ). For most studies in the database, calves fed HI started weaning at an age of 3 to 5 d older in relation to calves fed MOD and weaned over a period of $7 \mathrm{~d}$. It is not unusual to gradually wean calves in about $1 \mathrm{wk}$ when feeding a high level of MR on US dairy farms. In addition, to evaluate a milk or MR feeding program, a sufficient amount of time after weaning is required to properly address the effects on growth performance of dairy calves. However, many previous studies ended shortly after weaning: from a week to less than a month (Cowles et al., 2006; Omidi-Mirzaei et al., 2015; Rosen-

Table 8. Apparent digestibility of calves fed moderate or high rates of milk replacer (MR) estimated in a period of $5 \mathrm{~d}$

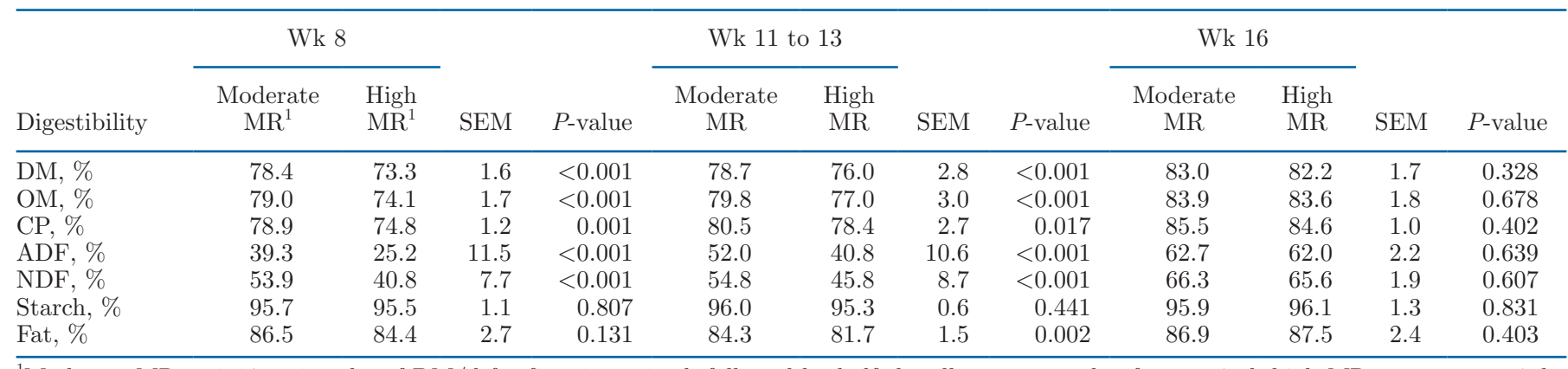

${ }^{1}$ Moderate $\mathrm{MR}=0.64$ to $0.66 \mathrm{~kg}$ of $\mathrm{DM} / \mathrm{d}$ for first 35 to $39 \mathrm{~d}$, followed by half the allotment per day for 3 to $7 \mathrm{~d}$; high $\mathrm{MR}=0.92$ to $1.07 \mathrm{~kg}$ of $\mathrm{DM} / \mathrm{d}$ for the first 35 to $44 \mathrm{~d}$, followed by half the allotment per day for 5 to $7 \mathrm{~d}$. 
berger et al., 2017). Gradual and later weaning of high feeding-rate MR yielded few to no benefits to growth to 16 -wk and post-weaning digestibility estimates, compared with similar feeding rates of MR with earlier or less-gradual weaning strategies (Dennis et al., 2108a, b; these treatments were not included in the current analysis). The studies undertaken at the Provimi Nurture Research Center over the last several years allowed us to combine the data available from multiple studies on calves in nursery and grower periods, thus re-evaluating the effects of feeding $\mathrm{HI}$ on growth performance in relation to MOD for dairy calves to 4 mo of age.

The MR intake of HI-fed calves during the first $5 \mathrm{wk}$ of life was $1.028 \mathrm{~kg} / \mathrm{d}, 57.7 \%$ greater MR consumption than MOD-fed calves $(0.652 \mathrm{~kg} / \mathrm{d}$; Table 4$)$. Starter intake rate began low and progressively increased to an amount of 0.261 or $0.532 \mathrm{~kg} / \mathrm{d}(P<0.001)$ at $\mathrm{d} 35$ for calves fed HI versus MOD (Figure 1). Calves often consume less starter when fed high amounts of milk or MR (Jasper and Weary, 2002; Kristensen et al., 2007; Khan et al., 2011), which was consistent with results observed in calves fed HI in the current study. Apparently, calves fed HI had a greater DM intake, albeit less starter intake, during the pre-weaning periods (5 wk), resulting in consumption of greater amounts of nutrients (CP, DP, fat, and ME; Table 4). Because calves fed MOD could not fully compensate by consuming more starter, feeding HI to calves during the pre-weaning period ( $5 \mathrm{wk}$ ) resulted in greater ADG. In contrast, during the weaning transition, greater reduction of MR offered to calves fed HI compared with MOD resulted in less nutrient intake (DM, CP, DP, NDF, and ME) and lower BW gain (Table 4). Although starter intake increased rapidly to compensate for the nutrient loss caused by reduction of MR intake during or after weaning in calves fed HI, a difference in starter intake on the last day of the nursery period (d 56) remained for calves fed HI compared with MOD (2.138 vs. 2.245 $\mathrm{kg} / \mathrm{d} ; P=0.006$; Figure 1).

Digestibility was measured in calves fed MOD or HI at 8,11 to 13 , or 16 wk of age. Digestibility of DM, $\mathrm{OM}, \mathrm{ADF}$, and NDF in the starter at wk 8 was lower for calves fed HI than in calves fed MOD; specifically, a larger difference in NDF and ADF digestibility occurred between the $2 \mathrm{MR}$ feeding rates. Although digestibility of DM, OM, CP, and NDF in calves fed HI improved with increasing age, it was evident that lower digestibility occurred at wk 11 to 13 in calves fed HI compared with those fed MOD. The lower nutrient digestibility in calves fed HI compared with MOD suggested less rumen development. Terré et al. (2006) reported less urine purine excretion (1.14 vs. $1.90 \mathrm{~mol} / \mathrm{d}$ of $\left.\mathrm{BW}^{0.75}\right)$, an indicator of microbial protein flow from the rumen, in calves fed larger amounts of MR in relation to calves fed the low MR feeding program. This indicated that the extent of rumen development was negatively affected in calves by feeding more MR. The earlier and greater ingestion of starter in calves fed MOD compared with $\mathrm{HI}$ in the current study implied that calves fed MOD might better prepare their rumen to develop sufficient physical capacity and absorptive surface area to utilize dry feed effectively. Recent evidence on successive dynamics of ruminal microbial communities of dairy calves (Dias et al., 2017) revealed that inclusion of starter in milk-fed calves, in relation to calves fed milk only, promoted greater diversity of bacterial taxa known to degrade readily fermentable carbohydrates in the rumen, which could lead to altered microbial fermentation and rumen metabolic development.

Starch digestibility was high (>95.0\%; Table 8$)$ and did not differ in calves fed either of $2 \mathrm{MR}$ feeding rates in 3 digestibility-measuring periods. It is not surprising that similar high starch digestibility occurred between the $2 \mathrm{MR}$ feeding rates, considering that starch is highly fermentable by microbes in both the rumen and the large intestine and digested in the small intestine by amylolytic enzymes. In addition, fat digestibility did not differ ( 86.5 vs. $84.4 \%$ ) at wk 8 but was greater at wk 11 to 13 ( 84.3 vs. $81.7 \%$ ) in calves fed MOD compared with HI. For fat digestibility measured postweaning during wk 8 , nevertheless, we speculated that feeding HI to calves would reduce fat digestibility. With a comparatively small difference of fat digestibility measured during wk 8 in calves fed MR at 2 feeding rates and relatively large variation, as indicated by standard errors of the mean (Table 8), it was unlikely that we would detect an effect of MR feeding rate on fat digestibility at a significant level. In fact, post hoc power calculations suggested that the sample size (n $=40$ ) of the current study would not be sufficient to detect the difference in fat digestibility measured during wk 8 , with power of test $=0.80$ and at a level of $P$ $<0.05$.

Feeding HI to calves not only improved ADG but also increased frame size in Holstein male calves in the pre-weaning period (d 0 to 35). However, calves fed HI versus MOD experienced a slump of growth during the weaning transition (d 35 to 56); moreover, ADG and hip width change in the grower period (d 56 to 112) were less. As previously mentioned, digestibility of DM, OM, CP, and NDF measured at wk 8 or 11 to 13 were greater, as diet digestion improved, more nutrients would be expected to be available for calves fed MOD than for those fed HI, to support growth in the post-weaning or extended week thereafter. Nevertheless, feeding more milk or MR pre-weaning obviously supplies more nutrients needed for rapid growth. Throughout the entire 112-d growth period, calves fed 
HI still had $2.35 \mathrm{~kg}$ more BW gain, resulting from their advantage in BW obtained during the first $5 \mathrm{wk}$. When comparing restricted MR ) feeding ( $23 \% \mathrm{CP}, 17 \%$ fat; $0.78 \mathrm{~kg}$ of $\mathrm{DM} / \mathrm{d})$ to ad libitum access to $\mathrm{MR}(>1.1$ $\mathrm{kg}$ of $\mathrm{DM} / \mathrm{d}$ ) during the first $4 \mathrm{wk}$ of life, pre-weaning ADG was greater for calves fed ad libitum MR, but BW was similar at $110 \mathrm{~d}$ of age (Korst et al., 2017). No data of structural growth measurement was available in the study of Korst et al. (2017).

In the current study, actual ADG in calves fed MOD or HI were less than the predicted growth rates allowed by amounts of energy and DP offered in the pre-weaning period or the entire nursery period (Table 5). For instance, actual ADG were 75.4 and $65.2 \%$ of predicted energy-allowable ADG from d 0 to 35 and were 86.8 and $73.8 \%$ of predicted energy-allowable ADG from 0 to $56 \mathrm{~d}$, respectively, for calves fed MOD compared with those fed HI. Morrison et al. (2009) reported that actual ADG were approximately $60 \%$ of the predicted when calves were offered MR at the high feeding rate $(10 \mathrm{~L} / \mathrm{d})$, and that most observed ADG were less than that predicted by NRC (2001) after reviewing several studies evaluating feeding rates of MR. The discrepancies between actual ADG and energy- or DP-allowable $\mathrm{ADG}$, in either the first $35 \mathrm{~d}$ or the entire nursery period (d 0 to 56), were smaller for calves fed MOD than for those fed HI $(P<0.001)$. Moreover, given the MR $(24.8$ to $28.6 \% \mathrm{CP}$ and 17.6 to $20.2 \%$ fat) fed to calves at 2 feeding rates, the predicted DP-allowable ADG was greater compared with the predicted energy-allowable ADG (Table 5; Figure 2). It appeared that calf growth was not limited by dietary energy offered pre-weaning, and if so, protein in the diet pre-weaning would probably be excessive, specifically for HI-fed calves. Chapman et al. (2017) indicated that calves fed MR and CP at greater rates [0.67 and $0.89 \mathrm{~kg} / \mathrm{d}$ of MR $(26 \% \mathrm{CP}$, $18 \%$ fat)] did not utilize dietary $\mathrm{N}$ as efficiently as did calves fed $\mathrm{MR}$ and $\mathrm{CP}$ at a lower rate $[0.45 \mathrm{~kg} / \mathrm{d}$ of $\mathrm{MR}$ (20\% CP, 20\% fat)].

Consistent with Rosenberger et al. (2017), similar $\mathrm{ADG} / \mathrm{ME}$ intake and $\mathrm{ADG} / \mathrm{CP}$ intake in the entire nursery period were observed in calves fed MR at 2 rates in the current study. Although HI-fed calves had greater feed efficiency in the nursery (Table 4), the feed efficiency of calves fed HI tended to be less during the weaning transition and was less in the grower period. Greater feed efficiency during the weaning transition and thereafter may be attributed to higher digestibility of OM, DM, CP, and NDF in MOD-fed calves.

Effects of feeding higher levels of milk or MR to calves on endocrine and metabolic status have been investigated (Schäff et al., 2016; Haisan et al., 2018). Calves fed higher levels of milk or MR had greater numbers of islets of Langerhans and insulin-stained area in the pancreas (Prokop et al., 2015) and greater plasma concentrations of insulin (Schäff et al., 2016) and IGF (Schäff et al., 2016; Haisan et al., 2018). Changes in intermediary metabolism or hormone signals altered by post-natal nutrition might influence calf nutrient utilization and efficiency for growth and may potentially cause epigenetic changes via processes of nutritional or metabolic programming, thus affecting future milk production. Soberon et al. (2012) reported positive effects on first-lactation milk production as a result of greater pre-weaning ADG through a higher level of MR feeding for nursery calves. On the contrary, a few studies have observed no response of milk performance in first-lactation dairy cows previously fed enhanced milk or MR (Raeth-Knight et al., 2009; Davis Rincker et al., 2011; Kiezebrink et al., 2015). Gelsinger et al. (2016) found, using meta-analytical methods, that although pre-weaning ADG was positively related to first-lactation milk production, its effect was minimal, with less than $3 \%$ of variation accounting for subsequent milk production response. Interestingly, Van Eetvelde and Opsomer (2017) developed an innovative view regarding the long-term effects of accelerated early calf growth by enhanced liquid feeding. They hypothesized that when an abundance of nutrients is available through enhanced feeding during the period of early life, a distinct mismatch occurs between the pre- and post-natal environment. In dairy cows, certain maternal or environmental factors create a suboptimal environment for fetal development, altering the phenotype of the newborn calf. The metabolic alteration prepares the newborn calf for similar conditions after birth. However, applying an accelerated feeding program to calves leads to early catch-up growth, which consequently might have detrimental influences on fertility, metabolic health, and lifespan in future dairy cows (Van Eetvelde and Opsomer, 2017).

The economics of raising calves is an important factor to consider when using increased amounts of milk or MR to achieve high pre-weaning growth rates. Obviously, feeding more MR to calves will cost more; with the ever-increasing price of high-quality proteins used in MR, this is especially pertinent in today's dairy economy for farms where calves are fed MR. In the current study, calves fed HI previously in the nursery consumed more MR (44.43 vs. $26.16 \mathrm{~kg}$ ) but less dry feed (191.43 vs. $196.51 \mathrm{~kg}$ ) throughout the entire period (d 0 to 112) compared with calves fed MOD. With 18.29 $\mathrm{kg}$ more MR and $5.08 \mathrm{~kg}$ less dry feed consumed, HI-fed calves gained $2.35 \mathrm{~kg}$ more BW from 0 to 4 mo of age. In this case we assumed a purchasing price of $\$ 2.65$ per $\mathrm{kg}$ of $\mathrm{MR}$ and $\$ 0.45$ per $\mathrm{kg}$ of starter (the difference between starter and dry feed due to $5 \%$ hay inclusion in the grower period was neglected); the total feed cost 
was $\$ 46.18$ more for raising a calf from 0 to 4 mo of age when fed HI, with an advantage of $2.35 \mathrm{~kg}$ more BW gain. Although greater BW gain was achieved, the MR cost for calves fed HI was much greater. Thus, results from the current study support an idea that a moderate milk or MR feeding program is feasible for dairy calves to achieve a reasonable pre-weaning ADG, while fostering starter consumption at an earlier age and steadily increasing calf starter intake would be beneficial to rumen development and structure growth, and economically sound.

One limitation in this report is that all data came from the Nurture Research Center. However, it has the strengths that data included a moderate feeding program that was similar for each trial, 6 to 8 weeks of pre-weaning data, 8 to 9 weeks of post-weaning data, individual animal data, data collected from all seasons of the year, and pre- and post-digestibility from multiple time points. Additional strengths were that feeds were manufactured sequentially within trial from the same ingredients, and calves were less than $4 \mathrm{~d}$ of age when the trials began.

\section{CONCLUSIONS}

Mixed model analysis of available data collated from 10 published studies in our research group showed that under the conditions of this study, MR at 2 feeding rates affected growth performance and nutrient digestion of dairy calves. Feeding more than 0.64 to $0.66 \mathrm{~kg} / \mathrm{d}$ of MR (24.8 to $28.6 \%$ CP, 17.6 to $20.2 \%$ fat) increased ADG and structural growth in the nursery period (d 0 to 56) but decreased ADG and structural growth in the grower period (d 56 to 112). The moderate MR feeding program appeared to better prepare calves for weaning. Feed efficiency was improved in calves fed MR at a rate of 0.64 to $0.66 \mathrm{~kg}$ of $\mathrm{DM} / \mathrm{d}$ throughout the period from 0 to $4 \mathrm{mo}$ of age. Greater total-tract digestibility of OM, DM, NDF, and ADF post-weaning in calves fed 0.64 to $0.66 \mathrm{~kg}$ of $\mathrm{DM} / \mathrm{d}$ of $\mathrm{MR}$ might partially explain why moderate MR feeding was more effective to support growth of dairy calves to 4 mo of age.

\section{ACKNOWLEDGMENTS}

This research was wholly funded by Provimi North America, a division of Cargill Animal Nutrition. The authors have not stated any conflicts of interest.

\section{REFERENCES}

Bach, A. 2012. Ruminant nutrition symposium: Optimizing performance of the offspring: Nourishing and managing the dam and postnatal calf for optimal lactation, reproduction, and immuni- ty. J. Anim. Sci. 90:1835-1845. https://doi.org/10.2527/jas.2011 -4516 .

Bach, A., M. Terré, and A. Pinto. 2013. Performance and health responses of dairy calves offered different milk replacer allowances. J. Dairy Sci. 96:7790-7797. https://doi.org/10.3168/jds.2013-6909.

Chapman, C. E., T. M. Hill, D. R. Elder, and P. S. Erickson. 2017. Nitrogen utilization, preweaning nutrient digestibility, and growth effects of Holstein dairy calves fed 2 amounts of a moderately high protein or conventional milk replacer. J. Dairy Sci. 100:279-292. https://doi.org/10.3168/jds.2016-11886.

Cowles, K. E., R. A. White, N. L. Whitehouse, and P. S. Erickson. 2006. Growth characteristics of calves fed an intensified milk replacer regimen with additional lactoferrin. J. Dairy Sci. 89:48354845. https://doi.org/10.3168/jds.S0022-0302(06)72532-2.

Davis Rincker, L. E., M. J. VandeHaar, C. A. Wolf, J. S. Liesman, L. T. Chapin, and M. S. Weber Nielsen. 2011. Effect of intensified feeding of heifer calves on growth, pubertal age, calving age, milk yield, and economics. J. Dairy Sci. 94:3554-3567. https://doi.org/ $10.3168 /$ jds.2010-3923

Dennis, T. S., F. X. Suarez-Mena, T. M. Hill, J. D. Quigley, and R. L. Schlotterbeck. 2017. Effects of egg yolk inclusion, milk replacer feeding rate, and low-starch (pelleted) or high-starch (texturized) starter on Holstein calf performance through 4 months of age. J. Dairy Sci. 100:8995-9006. https://doi.org/10.3168/jds.2017-13169.

Dennis, T. S., F. X. Suarez-Mena, T. M. Hill, J. D. Quigley, R. L. Schlotterbeck, and L. Hulbert. 2018a. Effect of milk replacer feeding rate, age at weaning, and method of reducing milk replacer to weaning on digestion, performance, rumination, and activity in dairy calves to 4 months of age. J. Dairy Sci. 101:268-278. https:/ /doi.org/10.3168/jds.2017-13692.

Dennis, T. S., F. X. Suarez-Mena, T. M. Hill, J. D. Quigley, R. L. Schlotterbeck, R. N. Klopp, G. J. Lascano, and L. Hulbert. 2018b. Effects of gradual and later weaning ages when feeding high milk replacer rates on growth, textured starter digestibility, and behavior in Holstein calves from 0 to 4 months of age. J. Dairy Sci. 101:9863-9875. https://doi.org/10.3168/jds.2018-15319.

Dennis, T. S., F. X. Suarez-Mena, W. Hu, T. M. Hill, J. D. Quigley, and R. L. Schlotterbeck. 2019. Effects of milk replacer feeding rate and long-term antibiotic inclusion in milk replacer on performance and nutrient digestibility of Holstein dairy calves up to 4 months of age. J. Dairy Sci. 102:2094-2102. https://doi.org/10.3168/jds .2018-15652.

Dias, J., M. I. Marcondes, M. F. Noronha, R. T. Resende, F. S. Machado, H. C. Mantovani, K. A. Dill-McFarland, and G. Suen. 2017. Effect of pre-weaning diet on the ruminal archaeal, bacterial, and fungal communities of dairy calves. Front. Microbiol. 8:1553. https: //doi.org/10.3389/fmicb.2017.01553.

Diaz, M. C., M. E. Van Amburgh, J. M. Smith, J. M. Kelsey, and E. L. Hutten. 2001. Composition of growth of Holstein calves fed milk replacer from birth to 105-kilogram body weight. J. Dairy Sci. 84:830-842. https://doi.org/10.3168/jds.S0022-0302(01)74541-9.

FASS (Federation of Animal Science Societies). 2010. Guide for the Care and Use of Agricultural Animals in Research and Teaching. 3rd ed. Fed. Anim. Sci. Soc., Champaign, IL.

Gelsinger, S. L., A. J. Heinrichs, and C. M. Jones. 2016. A metaanalysis of the effects of preweaned calf nutrition and growth on first-lactation performance. J. Dairy Sci. 99:6206-6214. https:// doi.org/10.3168/jds.2015-10744.

Haisan, J., M. Oba, D. J. Ambrose, and M. A. Steele. 2018. Short communication: The effects of offering a high or low plane of milk preweaning on insulin-like growth factor and insulin-like growth factor binding proteins in dairy heifer calves. J. Dairy Sci. 101:11441-11446. https://doi.org/10.3168/jds.2017-14339.

Hill, T. M., H. G. Bateman II, J. M. Aldrich, and R. L. Schlotterbeck. 2010. Effect of milk replacer program on digestion of nutrients in dairy calves. J. Dairy Sci. 93:1105-1115. https://doi.org/10.3168/ jds.2009-2458.

Hill, T. M., T. S. Dennis, F. X. Suarez-Mena, J. D. Quigley, K. M. Aragona, and R. L. Schlotterbeck. 2019. Effects of free-choice hay and straw bedding on digestion of nutrients in 7 -week-old Holstein 
calves. Appl. Anim. Sci. 35:312-317. https://doi.org/10.15232/aas 2019-01855.

Hill, T. M., J. D. Quigley, H. G. Bateman II, F. X. Suarez-Mena, T. S. Dennis, and R. L. Schlotterbeck. 2016a. Effect of milk replacer program on calf performance and digestion of nutrients in dairy calves to 4 months of age. J. Dairy Sci. 99:8103-8110. https://doi .org/10.3168/jds.2016-11239.

Hill, T. M., J. D. Quigley, F. X. Suarez-Mena, H. G. Bateman II, and R. L. Schlotterbeck. 2016b. Effect of milk replacer feeding rate and functional fatty acids on dairy calf performance and digestion of nutrients. J. Dairy Sci. 99:6352-6361. https://doi.org/10.3168/ jds.2015-10812.

Hill, T. M., J. D. Quigley, F. X. Suarez-Mena, T. S. Dennis, and R. L. Schlotterbeck. 2018. Case study: Control of respiratory disease in male Holstein calves with tildipirosin and effect on health and growth from 0 to 4 months of age. Prof. Anim. Sci. 34:118-123. https://doi.org/10.15232/pas.2017-01694.

Hu, W., T. M. Hill, T. S. Dennis, F. X. Suarez-Mena, J. D. Quigley, and R. L. Schlotterbeck. 2019. Intake, nutrient digestibility, and growth performance of Holstein dairy calves consuming a milk replacer at moderate or high feeding rates. J. Dairy Sci. 102:79177926. https://doi.org/10.3168/jds.2019-16282.

Jasper, J., and D. M. Weary. 2002. Effects of ad libitum milk intake on dairy calves. J. Dairy Sci. 85:3054-3058. https://doi.org/10.3168/ jds.S0022-0302(02)74391-9.

Kertz, A. F., and H. Chester-Jones. 2004. Invited review: Guidelines for measuring and reporting calf and heifer experimental data. J. Dairy Sci. 87:3577-3580. https://doi.org/10.3168/jds.S0022 -0302(04)73495-5.

Kertz, A. F., and J. R. Loften. 2013. Review: A historical perspective of specific milk-replacer feeding programs in the United States and effects on eventual performance of Holstein dairy calves. Prof. Anim. Sci. 29:321-332. https://doi.org/10.15232/S1080 -7446(15)30245-X.

Khan, M. A., D. M. Weary, and M. A. G. von Keyserlingk. 2011. Invited review: Effects of milk ration on solid feed intake, weaning, and performance in dairy heifers. J. Dairy Sci. 94:1071-1081. https://doi.org/10.3168/jds.2010-3733.

Kiezebrink, D. J., A. M. Edwards, T. C. Wright, J. P. Cant, and V. R. Osborne. 2015. Effect of enhanced whole-milk feeding in calves on subsequent first-lactation performance. J. Dairy Sci. 98:349-356. https://doi.org/10.3168/jds.2014-7959.

Korst, M., C. Koch, J. Kesser, U. Müller, F.-J. Romberg, J. Rehage, K. Eder, and H. Sauerwein. 2017. Different milk feeding intensities during the first 4 weeks of rearing in dairy calves: Part 1: Effects on performance and production from birth over the first lactation. J. Dairy Sci. 100:3096-3108. https://doi.org/10.3168/ jds.2016-11594.

Kristensen, N. B., J. Sehested, S. K. Jensen, and M. Vestergaard. 2007. Effect of milk allowance on concentrate intake, ruminal environment, and ruminal development in milk-fed Holstein calves. J. Dairy Sci. 90:4346-4355. https://doi.org/10.3168/jds.2006-885.

Lean, I. J., A. R. Rabiee, T. F. Duffield, and I. R. Dohoo. 2009. Invited review: Use of meta-analysis in animal health and reproduction: Methods and applications. J. Dairy Sci. 92:3545-3565. https://doi .org/10.3168/jds.2009-2140.

Morrison, S. J., H. C. F. Wicks, R. J. Fallon, J. Twigge, L. E. R. Dawson, A. R. G. Wylie, and A. F. Carson. 2009. Effects of feeding level and protein content of milk replacer on the performance of dairy herd replacements. Animal 3:1570-1579. https://doi.org/10 .1017/S1751731109990437.

NRC (National Research Council). 2001. Nutrient Requirements of Dairy Cattle. 7th rev. ed. Natl. Acad. Press, Washington, DC.

Omidi-Mirzaei, H., M. Khorvash, G. R. Ghorbani, B. Moshiri, M. Mirzaei, A. Pezeshki, and M. H. Ghaffari. 2015. Effects of the step-up/step-down and step-down milk feeding procedures on the performance, structural growth, and blood metabolites of Holstein dairy calves. J. Dairy Sci. 98:7975-7981. https://doi.org/10.3168/ jds.2014-9260.

Prokop, L., M. Kaske, P. Maccari, R. Lucius, H.-J. Kunz, and S. Wiedemann. 2015. Intensive rearing of male calves during the first three weeks of life has long-term effects on number of islets of Langerhans and insulin stained area in the pancreas. J. Anim. Sci. 93:988-998. https://doi.org/10.2527/jas.2014-8144.

Quigley, J. D., L. Deikun, T. M. Hill, F. X. Suarez-Mena, T. S. Dennis, and W. Hu. 2019a. Effects of colostrum and milk replacer feeding rates on intake, growth, and digestibility in calves. J. Dairy Sci. 102:11016-11025. https://doi.org/10.3168/jds.2019-16682. In press.

Quigley, J. D., T. M. Hill, T. S. Dennis, F. X. Suarez-Mena, and R. L. Schlotterbeck. 2018. Effects of feeding milk replacer at 2 rates with pelleted, low-starch or texturized, high-starch starters on calf performance and digestion. J. Dairy Sci. 101:5937-5948. https:// doi.org/10.3168/jds.2017-13851.

Quigley, J. D., W. Hu, J. R. Knapp, T. S. Dennis, F. X. Suarez-Mena, and T. M. Hill. 2019b. Estimates of calf starter energy affected by consumption of nutrients. 2. Effect of changing digestion on energy content in calf starters. J. Dairy Sci. 102:2242-2253. https://doi .org/10.3168/jds.2018-15354.

Raeth-Knight, M., H. Chester-Jones, S. Hayes, J. Linn, R. Larson, D. Ziegler, B. Ziegler, and N. Broadwater. 2009. Impact of conventional or intensive milk replacer programs on Holstein heifer performance through six months of age and during first lactation. J. Dairy Sci. 92:799-809. https://doi.org/10.3168/jds.2008-1470.

Rosenberger, K., J. H. C. Costa, H. W. Neave, M. A. G. von Keyserlingk, and D. M. Weary. 2017. The effect of milk allowance on behavior and weight gains in dairy calves. J. Dairy Sci. 100:504-512. https://doi.org/10.3168/jds.2016-11195.

Roth, B. A., N. M. Keil, L. Gygax, and E. Hillmann. 2009. Influence of weaning method on health status and rumen development in dairy calves. J. Dairy Sci. 92:645-656. https://doi.org/10.3168/ jds.2008-1153.

SAS Institute Inc. 2012. Enterprise Guide 5.1. SAS Institute Inc., Cary, NC.

Schäff, C. T., J. Gruse, J. Maciej, M. Mielenz, E. Wirthgen, A. Hoeflich, M. Schmicke, R. Pfuhl, P. Jawor, T. Stefaniak, and H. M. Hammon. 2016. Effects of feeding milk replacer ad libitum or in restricted amounts for the first five weeks of life on the growth, metabolic adaptation, and immune status of newborn calves. PLoS One 11:e0168974. https://doi.org/10.1371/journal.pone.0168974.

Soberon, F., E. Raffrenato, R. W. Everett, and M. E. Van Amburgh. 2012. Preweaning milk replacer intake and effects on long-term productivity of dairy calves. J. Dairy Sci. 95:783-793. https://doi .org/10.3168/jds.2011-4391.

Steele, M. A., J. H. Doelman, L. N. Leal, F. Soberon, M. Carson, and J. A. Metcalf. 2017. Abrupt weaning reduces postweaning growth and is associated with alterations in gastrointestinal markers of development in dairy calves fed an elevated plane of nutrition during the preweaning period. J. Dairy Sci. 100:5390-5399. https:// doi.org/10.3168/jds.2016-12310.

Terré, M., M. Devant, and A. Bach. 2006. Performance and nitrogen metabolism of calves fed conventionally or following an enhancedgrowth feeding program during the preweaning period. Livest. Sci. 105:109-119. https://doi.org/10.1016/j.livsci.2006.05.001.

Van Eetvelde, M., and G. Opsomer. 2017. Innovative look at dairy heifer rearing: Effect of prenatal and post-natal environment on later performance. Reprod. Domest. Anim. 52(Suppl. 3):30-36. https://doi.org/10.1111/rda.13019.

\section{ORCIDS}

W. Hu ৫ https://orcid.org/0000-0002-1307-3458

T. M. Hill ๑ https://orcid.org/0000-0003-1304-5016

T. S. Dennis @ https://orcid.org/0000-0003-3424-5498

F. X. Suarez-Mena @ https://orcid.org/0000-0002-1546-5893

K. M. Aragona @ https://orcid.org/0000-0003-3674-838X

J. D. Quigley (i) https://orcid.org/0000-0001-8400-8963

R. L. Schlotterbeck • https://orcid.org/0000-0002-5305-3945 